Short Title: Leader Charisma Increases Post-Mortem

\title{
Dying for Charisma: Leaders' Inspirational Appeal Increases Post-Mortem
}

\section{Cite as:}

Steffens, N.K., Peters, K., Haslam, S.A., \& Van Dick, R. (in press). Dying for Charisma: Human inspirational appeal increases post-mortem. Leadership Quarterly

\begin{abstract}
In the present research, we shed light on the nature and origins of charisma by examining changes in a person's perceived charisma that accompany their death. We propose that death is an event that will strengthen the connection between the leader and the group they belong to, which in turn will increase perceptions of leaders' charisma. In Study 1, results from an experimental study show that a scientist who is believed to be dead is regarded as more charismatic than the same scientist believed to be alive. Moreover, this effect was accounted for by people's perceptions that the dead scientist's fate is more strongly connected with the fate of the groups that they represent. In Study 2, a large-scale archival analysis of Heads of States who died in office in the $21^{\text {st }}$ century shows that the proportion of published news items about Heads of State that include references to charisma increases significantly after their death. These results suggest that charisma is, at least in part, a social inference that increases after death. Moreover, they suggest that social influence and inspiration can be understood as products of people's capacity to embody valued social groups.
\end{abstract}

Keywords: charisma; inspiration; leadership; identity; death 


\section{Introduction}

A great deal of research and theory suggests that individuals who are perceived to be charismatic are especially influential when it comes to shaping other people's thoughts, feelings, behaviors, and the organizations they are part of (Aral \& Walker, 2012; Bass \& Riggio, 2006; Bryman, 1992; Burns, 1978; Conger \& Kanungo, 1998; House, 1977; Waldman, Ramirez, House, \& Puranam, 2001). Indeed, meta-analytic evidence indicates that a person's charisma is central to their capacity for leadership (Judge \& Piccolo, 2004; Lowe, Kroeck, \& Sivasubramaniam, 1996; Wang, Oh, Courtright, \& Colbert, 2011). In line with this, empirical and historical analyses are replete with examples of leaders of nations whose charisma is seen as having allowed them to mobilize citizens to perform exceptional behaviors, both moral and immoral (House, Spangler, \& Woycke, 1991; Rees, 2012).

However, we know little about the social factors that underpin charisma. Yet building such an understanding is important in light of evidence that charismatic leadership is a pathway to outstanding leadership (Ligon, Hunter, \& Mumford, 2008; Mumford, 2006; Mumford, Hunter, Friedrich, \& Caughron, 2009; O'Connor, Mumford, Clifton, Gessner, \& Connelly, 1995; Simonton, 2009) and consequently to the societal achievements that can accompany this leadership. In the present research, we seek to advance our understanding of the nature and origins of charisma. We do this by examining the impact of a person's death on observers' inclination to see them as charismatic. We argue that following a person's death, people will perceive a stronger connection between an individual and the social groups that they belong to, and that this can increase their charismatic appeal (Steffens, Haslam, \& Reicher, 2014). To the extent that this holds true, it speaks to claims that charisma is a social inference that, at least in part, is informed by a person's capacity to embody important social groups. 
The present research makes at least three important contributions to the literatures on leadership, charisma, and identity. First, it extends our understanding of the nature of charisma. Previous research has tended to treat charisma as a more or less stable individual difference variable and, consequently has taken individual differences as a starting point for understanding the consequences of charisma (for a recent comprehensive review, see Antonakis, Bastardoz, Jacquart, \& Shamir, 2016). In the present research, in contrast, we elaborate on work that sees charisma as a malleable, context-sensitive, and conferred characteristic by examining the factors that underpin people's perceptions of leader charisma. Second, we advance previous work on the social construction of charisma (Meindl, 1995; Shamir, 1992) by showing that charisma is conferred on leaders not only on the basis of their own achievements and those of their group but also as a consequence of their death. Third, we extend the literature on identity and leadership which has argued that leadership is necessarily a group process (Thomas, Martin, \& Riggio, 2013; Platow, Haslam, Reicher, \& Steffens, 2015). Specifically, in the present research, we elaborate on the importance of group-based concerns by explaining why a person's charisma continues to grow following death. More specifically, we do this by exploring how a dead leader's fusion with the collective identity that he or she represented can account for post-mortem increase in their charisma.

\section{Charisma and its Underpinnings}

A leader's charisma is seen as lying at the heart of his or her capacity to enact transformational leadership (Bass, 1985). In light of the evidence that charismatic and transformational leaders are more effective than their non-charismatic and nontransformational counterparts (Judge \& Piccolo, 2004; Lowe et al., 1996; Wang et al., 2011), there is a great deal of interest in understanding what leaders can do to increase their charisma. There are two important broad classes of answers to this question. The first 
emphasizes the importance of having (or being perceived as having) the right qualities as an individual (e.g., Den Hartog \& Venburg, 1997), while the second emphasizes the importance of social factors in people's inferences of charisma (e.g., Meindl, Ehrlich, \& Dukerich, 1985).

Evidence for the former position comes from research suggesting that a person's charisma arises from his or her qualities as an individual or his or her skills, character, or personality (Antonakis, Fenley, \& Liechti, 2011; Bass \& Riggio, 2006; House \& Howell, 1992; Keller, 2006; Waldman et al., 2001). For instance, it has been suggested that leaders are more charismatic to the extent that they are, among other things, able to challenge the status quo and communicate an inspiring vision for the future (Conger \& Kanungo, 1987). There are also suggestions that leaders' rhetorical style can influence perceptions of charisma (Berson, Shamir, Avolio, \& Popper, 2001; Den Hartog, \& Verburg, 1997; Emrich, Brower, Feldman, \& Garland, 2000; Shamir, Arthur, \& House, 1994). For instance, evidence indicates that compared to their less charismatic counterparts, charismatic leaders more often make use of metaphors in their rhetoric (Mio, Riggio, Levin, \& Reese, 2005), and use more vivid imagery (Seyranian \& Bligh, 2008).

Support for the latter analysis comes from evidence that perceivers infer charisma on the basis of a person's perceived achievements (Meindl et al., 1985; Schyns, Felfe, \& Blank, 2007; van Knippenberg \& Sitkin, 2013; Weber, 1992). In particular, research suggests that a person's charismatic appeal is associated with their exertion of effort on behalf of a group (Howell \& Shamir, 2005) and that it derives from their relationship with, and perceived embodiment of, the social group to which they belong (Haslam, 2004). For instance, Platow, van Knippenberg, Haslam, van Knippenberg, and Spears (2006; see also Steffens et al., 2014; van Knippenberg \& van Knippenberg, 2005) found that leaders who were more prototypical of an ingroup were perceived to be more charismatic than leaders who were less prototypical. Moreover, in a recent analysis of Steve Job's rhetoric, Heracleous and Klaering (2014) 
argued that his charismatic qualities appeared to reside as much in his capacity to shape his rhetoric in response to the immediate social context as in his use of particular metaphors.

\section{Death and Charisma}

The death of leaders and its social consequences has attracted very little research attention in the social sciences. However, there are two notable exceptions to this. The first is economic analysis by Jones and Olken (2005) that used the death of national political leaders as an exogenous variable in an analysis of the impact of leaders on economic growth (finding that leaders impact economic growth, and more so in autocratic than democratic regimes). The second is a recent analysis by Yammarino, Mumford, Serban, and Shirreffs (2013; see also Simonton, 1991) that examined the association between leadership style and assassinations in a political context. Focusing on U.S. Presidents, the researchers found that presidents who were coded as charismatic were particularly likely to be targeted in assassination attempts or actually assassinated. While Yammarino and colleagues approach these analyses from the perspective that a charismatic leadership style may play a causal role in the likelihood of a subsequent assassination, the reverse causal direction is also possible. That is, it is possible that the death of a leader while in office boosts subsequent perceptions of that leader's charisma.

There is additional indirect evidence that is consistent with the possibility that death may elevate inferences of charisma. This arises from literature on mortality salience which has shown that priming cognitions around death leads to the elevated endorsement of cognitions and behaviors that are consistent with valued group memberships (e.g., Burke, Martens, \& Faucher, 2010; Greenberg, Simon, Pyszczynski, Solomon, \& Chatel, 1992). In other words, death is associated with group-based cognition and behavior. To the extent that charisma is a social group-based inference (Haslam, Reicher, \& Platow, 2011; Platow et al., 2006; Steffens et al., 2014; van Knippenberg \& van Knippenberg, 2005), this suggests that 
death may feed into increased inferences of charisma. Specifically, charisma may increase post-mortem because people regard the dead from the perspective of what they meant to others and see their fate as overlapping with the fate of the collective that they represented. Consistent with this possibility, there is evidence that under conditions of mortality salience, people are more supportive of leaders who are described as having attributes believed to be characteristic of charisma (Cohen, Solomon, Maxfield, Pyszczynski, \& Greenberg, 2004; Kosloff, Greenberg, \& Solomon, 2010). Accordingly, we propose that a dead leader's perceived fusion (Swann, Jetten, Gómez, Whitehouse, \& Bastian, 2012) with the collective identity that this leader represented is likely to account for the proposed death-charisma link. This proposition aligns with research from other disciplines (art, music, celebrity culture) that has investigated the consequences that a person's death can have for the public's appreciation of that person's artistic output. Research in this area has shown that death can increase (a) the value of an artist's oeuvre (Ursprung \& Wiermann, 2011), (b) the sales of a musician's creative works (Brandes, Nüesch, \& Franck, 2016), and (c) the value of celebrity memorabilia (Radford \& Bloch, 2013). Together, this body of research intimates that a person's death sparks a celebration and greater appreciation of their creative achievements. Beyond this, though, we suggest that similar processes may lead to an increased appreciation of a deceased leader's connection to the collective, and consequently, of their charisma. These ideas can be formalized in the following hypotheses:

H1. Perceptions of a leader's charisma will increase following his or her death.

H2. Identity fusion will mediate the impact of a leader's death on his or her charisma. That is, a dead leader will be seen to be more strongly fused with the collective he or she represented, which, in turn, will be positively associated with perceptions of leader charisma. 


\section{Overview of Present Research}

Across two studies — an experiment and a large-scale archival study — we examine the impact of death on charisma. In Study 1, we examine the causal impact of a leader's death on their charisma by presenting participants with information about a scientific leader who is dead versus alive and by assessing their perceptions of that leader's identity fusion and their charisma (to test $\mathrm{H} 1$ and $\mathrm{H} 2$ ). In Study 2, we provide a more general examination of the death-charisma link in a large-scale archival analysis of news reports of Heads of State who died in office in the $21^{\text {st }}$ century (providing a further test of $\mathrm{H} 1$ ). We quantify the proportion of news items about a Head of State that reference charisma and examine the extent to which the proportion of charisma-referencing news items increases post-mortem.

\section{Study 1}

Our first study was an experiment designed to establish the causal role that death plays in perceptions of charisma. This involved manipulating information about a particular scientific leader (Richard Din) such that they were thought to be either alive or dead and then investigating the impact of this on perceptions of leader charisma.

\section{Method}

Participants and design. The study was approved by the Behavioral and Social Sciences Ethical Review Committee at the first author's university (Ref: 2014001440). We recruited 400 US adults through Amazon's Mechanical Turk who provided informed consent to participate in the study. MTurk samples have unique advantages and limitations (for recent discussions, see Harms \& DeSimone, 2015; Landers \& Behrend, 2015) that are important to consider in the context of the aim and design of any given study. In particular, one of main perceived risks of MTurk samples is that they are likely to provide relatively invariant responses (i.e., generating data that is insufficiently differentiated across constructs). Importantly, though, the use of the present study's experimental design means that any 
differences between conditions cannot be explained by invariant responses (indeed, if anything, it provides a more conservative test of our hypotheses).

We aimed to obtain a minimum of 360 final responses such that for a small effect of $d$ $=.03$ (an effect that exceeded in magnitude about $20 \%$ of effect sizes found in the past 30 years in meta-analyses in HR/OB literatures; Paterson, Harms, Steel, \& Credé, 2016), the statistical power to detect a true effect would be greater than .80 . In line with the recommendations for best practice provided by DeSimone, Harms, and DeSimone (2015) we also sought to ensure high-quality data through inclusion of a screening process in which participants responded to two "instructed items" (e.g., "This is a control question: Please select ' 2 ' "). Seven participants who failed to respond as instructed and one participant who failed to provide full responses to dependent measures were subsequently excluded from analysis. This left 392 participants (female $\left.=187, M_{\mathrm{age}}=37.22, S D=12.40\right)$ who were randomly assigned to one of two experimental conditions (alive vs. dead target person).

Procedure and measures. Participants were invited to take part in a survey about "People's opinions about various public people". They then read a short biography of American bio-medical scientist Richard Din who died in April 2012. Participants were provided with a 300-word summary about Din's work that centered on the development of a vaccine that would protect people against the bacterium, Neisseria meningitides. All participants read the same biography. However, in the control 'alive' condition, the article was entitled 'Life of a scientific crusader' and there was no mention of Din having died. In the experimental 'dead' condition, the article was entitled 'Death of a scientific crusader' and Din's death was made salient in a final paragraph which noted the fact that he had died (as a result of a disease that originated from the bacterium he was working on).

The experimental design — including excerpts from the biography of the alive and dead scientist, Richard Din — is represented in Figure 1. We refrained from using a 
manipulation check in this experiment in order to avoid the risk that asking people the question of whether the leader was alive or dead might have alerted them to the aim of the study (especially in light of the stated study purpose of ascertaining 'people's opinions about various public people') and thus increased reactivity (e.g., in the form of demand characteristics). After reading the biography, participants responded on Likert scales ranging from 1 (not at all) to 7 (completely) to the following measures before they provided demographic data and were debriefed.

Fusion with America. Participants provided ratings of the degree to which the target person was seen to be connected (i.e., 'fused') with America using the 7-item Identity Fusion Scale from Gómez, Brooks, Buhrmester, Vázquez, Jetten, and Swann (2011; $\alpha=$.90; “Din had a deep emotional bond with his country (the USA)"; "Din was one with his country"; "Din felt immersed in his country"; "Din did for his country more than other Americans would do"; "Din was strong because of his country"; "Din made his country strong"; "His country was Din"). ${ }^{1}$

Charisma. We used an adapted version of the eight-item Attribution of Leader Charisma Scale (ALCS) from Platow and colleagues (2006) to assess charisma. This construct is conceptually equivalent to the construct that is captured by the Multifactor Leadership Questionnaire (MLQ; Bass \& Avolio, 2004) but, unlike the MLQ, is freely available for research purposes. In the interest of conceptual and empirical clarity, we reviewed these items according to guidelines provided by Antonakis et al. (2016) for defining and measuring charisma (see common elements presented in Table 1). This resulted in a refined three-item charisma scale ( $\alpha=.78$; "Din had a compelling vision for the future"; "Din was an inspiring person"; Din had a sense of mission") from which the following items were excluded: "Din was a charismatic person" (which fails because it reflects the definition of the latent variable), "Din had a special gift for seeing what is worthwhile" (which fails because it 
relates to a quality, ability, or gift of the leader; Element 1), and "Din motivated people to see that they can do more than they think they can", "Din increased others" optimism for the future", and "Din gave people a sense of overall purpose" (which fail because they relate to outcomes; Element 3). Note, though, that the results that we report below are virtually identical for the full eight-item scale. ${ }^{2}$

\section{Results}

Preliminary analyses. Means, standard deviations, and bivariate correlations are presented in Table 1. We conducted confirmatory factor analyses (CFAs) of a model (Model A) with the three charisma and seven fusion items loading on two separate factors to examine its fit with the data. We also compared this model to an alternative one-factor model (Model B) that combined the charisma and fusion items in a single undifferentiated factor. We examined these alternative models by inspecting the overall chi-square $\left(\chi^{2}\right)$ and the fit indices standardized root mean square residuals (SRMR), root mean square error of approximation (RMSEA), and comparative fit (CFI; Hooper, Coughlan, \& Mullen, 2008). Because preliminary analyses indicated that we could not assume normal distribution of the responses to items, we used the Satorra-Bentler corrected chi-square model test.

Results revealed that Model A had a moderate fit to the data $\left(\chi^{2}=188.73, d f=42\right.$, $C F I=.932, R M S E A=.100,90 \% C I s[.087, .114], S R M R=.067)$. A significant chi-square indicated some level of model misspecification, suggesting that estimates could be biased (Kline, 2015). Results indicated that Model B had a poorer fit to the data $\left(\chi^{2}=439.55, d f=\right.$ $44, C F I=.811, R M S E A=.163,90 \% C I s[.150, .176], S R M R=.107)$. Examining the charisma and the fusion scales separately indicated that while the model in which charisma items loaded on a single factor converged (as indicated by a non-significant chi-square: $\chi^{2}=1.09$, $d f=2$ ), the model in which fusion items loaded on a single factor did not (as indicated by a significant chi-square: $\chi^{2}=102.35, d f=20$ ). This suggests that model misspecification is 
mainly due to the fusion scale. In sum, results indicate that the data fitted a model that treats charisma and fusion as distinct factors better than a model that treats these as a single undifferentiated factor. Nevertheless, some caution should be exercised when considering the results we report below due to evidence of some misspecification in this two-factor model. We return to these issues of conceptualization and measurement in the General Discussion.

Main analyses. Means within experimental cells, inferential statistics, and effect sizes are presented in Table 2. We conducted a multivariate analysis of variance (MANOVA), which yielded a significant effect of experimental condition on fusion with America and charisma, Wilk's lambda $=.97, F(2,390)=6.46, p=.002$. Results were followed by a series of analyses of variance (ANOVAs) to assess the impact of the experimental condition on each dependent measure.

Fusion with America. Analysis of variance revealed a significant effect of experimental condition on fusion with America, $F(1,390)=9.81, p=.002, M D=.38$, 95\%CIs $[.14, .61], d=.32$. Participants regarded the target person (Din) to be more fused with America when he was believed to be dead $(M=4.63,95 \%$ CIs $[4.46,4.80])$ than when he was believed to be alive $(M=4.25,95 \%$ CIs $[4.01,4.42])$.

Charisma. Analysis revealed a significant effect of experimental condition on charisma, $F(1,390)=7.58, p=.006, M D=.23,95 \%$ CIs $[.07, .39], d=.28$. Supporting H1, participants perceived the target person (Din) to be more charismatic when he was believed to be dead $(M=6.15,95 \%$ CIs $[6.04,6.27])$ than when he was believed to be alive $(M=5.93$, 95\% CIs $[5.81,6.04]) .{ }^{3,4}$

Indirect effect. Prior to examining the mediational role of fusion with America, we tested whether this variable violated assumptions of non-endogeneity (Antonakis, Bendahan, Jacquart, \& Lalive, 2010; 2014). To do this, we ran a two-stage least squares instrumentalvariable regression using the experimental manipulation as the instrumental variable. The 
Durbin-Wu-Hausman test for endogeneity of the mediator was not significant, $\mathrm{Wu}-\mathrm{Hausman}$ $F(1,389)=3.18, p=.08$. To test the indirect pathway of experimental condition through the target's connectedness with the collective, we conducted bias-corrected bootstrapping with 5000 resamples using PROCESS (Model 4; Hayes, 2013). Supporting H2, and as shown in Figure 2, analysis revealed an indirect effect through perceptions of Din's connectedness with America to charisma, $\gamma=.09, S E=.03,95 \%$ CIs $[.03, .16]$. When participants were told that Din was dead they saw him to be more connected with America, and this, in turn, led them to see him as more charismatic.

As an additional test of the proposed meditation, we also ran structural equation modeling with the experimental manipulation as the instrumental variable (and with fusion and charisma as latent factors). This yielded largely identical results. Analysis revealed an indirect effect of the experimental condition through perceptions of Din's connectedness with America to charisma, $\gamma=.21, S E=.08,95 \%$ CIs $[.06, .37]$.

\section{Discussion}

Results provide causal evidence to support the hypothesis that charisma increases post-mortem. In line with $\mathrm{H} 1$, a leader who was believed to be dead was regarded as more charismatic than that same person when they were believed to be alive. Moreover, in line with $\mathrm{H} 2$, this pattern of findings was accounted for by the extent to which the dead leader was seen to be fused with the collective that they represented (America). In other words, a leader who was understood to be dead (rather than alive) was seen to be more at one with America, and this, in turn, led to them being seen as more charismatic.

\section{Study 2}

In Study 1 the death-charisma effect was observed for a target person who worked in a domain (bacteriology) that can be regarded as demanding self-sacrifice. As a result, it is not possible to determine from these findings whether support for our hypotheses is specific to a 
particular cause of death (e.g., one that can be seen as in some sense heroic). To rule out this possibility, we conducted a large-scale archival study of Heads of State who died in office in the $21^{\text {st }}$ century. This also allowed us to examine whether the findings concerning a leader occupying a role that is somewhat less stereotypical of leadership roles (a scientific leader) also transfer to leaders in a more stereotypical leadership domain — namely, politics.

\section{Method}

Sample. An archival search of the updated version of the Archigos Dataset of Political Leaders (Goemans, Gleditsch, \& Chiozza, 2009) and the Internet's largest encyclopedia Wikipedia (Wikipedia, 2015) identified a total population of 48 Heads of Nation States (Prime Minister, President, King, Supreme Leader, Emir) who died in office between 2000 and 2013 (inclusive). All 48 Heads of State were male and their age at death ranged from 41 to 94 years $(M=66.48 ; S D=12.25)$.

Procedure. We conducted a search for all media reports concerning the Heads of State using the global news and business information database Factiva operated by Dow Jones \& Company (2015). Factiva is a database that allows aggregated keyword-based searches of both licensed and free online published content in 28 languages worldwide, including news and business websites, journals, magazines, television and radio transcripts, and photos. We conducted a search of all published content that referred to the full name of a given Head of State. We also conducted a search for published content that referred to the full name of a given Head of State as well as the keyword "charisma*". We calculated the percentage of all publications about a Head of State that included charisma by dividing the number of items that mentioned a given Head of State together with charisma by the total number of items that mentioned a given Head of State.

We conducted separate searches to calculate the percentage of charisma-referencing items both (a) during a Head of State's lifetime and (b) from the time of his death until the 
cut-off date at the time the data collection and analysis were completed (01 March 2015). We focused on Heads of State in the $21^{\text {st }}$ century because in the $20^{\text {th }}$ century the overall volume of items that are tracked by Factiva is low, increasing substantially with the turn of the millennium. For illustrative purposes, there are a total of 0.076 million tracked items $(7$ items that mention charisma) in 1970, 0.280 million (175 items that mention charisma) in 1980, 2.598 million (4,035 that mention charisma) in 1990, but this then increases to 17.596 million (21,899 chat mention charisma) in 2000 and 60.041 million (40717 that mention charisma) in 2010. The search identified a total of $1,887,993$ published news items referencing the Heads of State during their lifetime and a total of 514,178 news items published after their death. On average, Heads of State were discussed in 39,333 items before death and 10,712 news items after death. Further inspection indicated that obituaries accounted for a small minority of identified news items and that their exclusion did not alter the pattern of the findings. Accordingly, they were retained in the final analyses.

\section{Results}

Main analyses. In line with our hypothesis, the unit of analysis was Heads of State ( $n$ $=48$ ). Because the data were not normally distributed (Shapiro-Wilk test for charisma references ante-mortem: $W(48)=.458, p<.001$; post-mortem: $W(48)=.764, p<.001)$ they were analyzed using the Wilcoxon Signed-Ranks test. Results are displayed in Figure 3. As this figure shows, the percentage of charisma-referencing items increased post-mortem for 27 Heads of State, while it decreased for 13, and remained the same for 8 Heads of State. Analysis revealed a significant difference in the percentage of charisma-referencing items that appeared before versus after death, $Z=2.90, p=.004$ (two-sided). The percentage of charisma-referencing items increased from a median of .29\% (Interquartile Range: .14\%, $.42 \%$ ) during a Head of State's lifetime to a median of .58\% (Interquartile Range: .05\%, $1.02 \%$ ) after his death, corresponding to a $100.07 \%$ post-mortem increase in charisma- 
referencing published content (from every $343^{\text {rd }}$ item ante-mortem to every $172^{\text {nd }}$ item postmortem).

Sensitivity analyses. To establish the robustness of the evidence of the deathcharisma relationship, we conducted several sensitivity analyses that examined the extent to which results change if additional variables are accounted for. To rule out the possibility that results are explained by a general increase in references to charisma over time, we conducted an additional search for the one-year periods before and after death. The numbers of published news items referencing the Heads of State within the one-year ante-mortem and post-mortem periods were 247,232 and 226,720 , respectively. In the one-year ante-mortem and post-mortem periods, a Head of State was discussed on average in 5,151 and 4,723 news items, respectively. The data were not normally distributed (Shapiro-Wilk test for charisma references one-year ante-mortem: $W(48)=.626, p<.001$; one-year post-mortem: $W(48)=$ $.716, p<.001)$, and so were analyzed by means of a Wilcoxon Signed-Ranks test.

Analysis of the one-year ante-mortem and post-mortem periods yielded similar results to our main analysis, $Z=4.43, p<.001$. The percentage of charisma-referencing items increased for 29 Heads of State, decreased for 2, and remained the same for 17. Here the percentage of charisma-referencing items increased from a median of .12\% (Interquartile Range: $.00 \%, .30 \%$ ) during a Head of State's lifetime to a median of $.42 \%$ (Interquartile Range: $.00 \%, .94 \%$ ) after his death, indicating that the charisma-referencing published content increased from every $854^{\text {th }}$ item ante-mortem to every $239^{\text {th }}$ item post-mortem.

To further test the robustness of the present patterns, we removed the statistical outliers (+/- $3 \mathrm{SD})$ in percentage of charisma-referencing items for both the total time (lifetime and post-mortem) and the one-year (pre and post-death) periods. Removal of two outliers (John Paul II and John Atta Mills) in the total lifetime and post-mortem periods yielded largely identical results. A Wilcoxon Signed-Ranks test revealed a significant 
difference in the percentage of charisma-referencing items that appeared before versus after death, $Z=3.14, p=.002$. Analysis of the one-year periods after removal of three outliers (John Paul II, John Atta Mills, and Hugo Chávez) yielded virtually identical results with a significant increase in charisma references post-mortem, $Z=4.53, p<.001$. Note that excluding Ibrahim Rugova (who may appear like an outlier even though data points not exceed $+/-3 \mathrm{SD})$ also led to virtually identical results $(Z=2.98, p=.003$ and $Z=4.45, p<$ .001 , for total and one-year periods, respectively).

Furthermore, we conducted an analysis for the keyword "vision*". Analysis yielded largely identical results. Vision-referencing published items in the in the total lifetime and post-mortem periods increased in the case of 40 Heads of State, while it decreased in the case of 7 , and remained the same in the case of $1, Z=4.80, p<.001$. The percentage of visionreferencing items increased from a median of $1.54 \%$ (Interquartile Range: .72\%, 2.76\%) ante-mortem to a median of $2.82 \%$ (Interquartile Range: $1.84 \%, 5.59 \%$ ) post-mortem. In the one-year ante-mortem and post-mortem periods vision-referencing published items increased too, $Z=3.39, p=.001$, from a median of $1.60 \%$ (Interquartile Range: $.82 \%, 2.83 \%$ ) to a median of $2.65 \%$ (Interquartile Range: $1.30 \%, 5.56 \%$ ).

Finally, we ran discontinuity regression analysis (Thistlethwaite \& Campbell, 1960; Cook, 2008; see also Antonakis et al., 2010) to examine whether the slope of charismareferences per unit of time differed between the pre- and post-death periods. This involved computing the proportion of charisma references in 6-monthly intervals from two years predeath to two years post-death (intervals that gave us sufficient precision while minimizing the amount of missing data in our analysis). We created a time variable that had pre-death values of -4 (24 to 18 months), -3 (18 to 12 months), -2 (12 to 6 months), and -1 (6 months predeath to date of death) and values for each consecutive 6-month-interval after death of +1 , $+2,+3$, and +4 . We also created a death dummy variable $(0=$ before death; $1=$ after death $)$. 
We regressed the proportion of charisma references on the death dummy variable, on the time variable, and on the two-way interaction between these variables. Results revealed a significant effect of death $(\gamma=.0055, S E=.0015, t=3.50, p<.001)$, a non-significant effect of time $(\gamma=-.0003, S E=.0002, t=1.20, p=.235)$, and a non-significant interaction between death and time $(\gamma=-.0001, S E=.0005, t=.05, p=.960)$. This indicates that the proportion of charisma-references showed a significant step increase with a Head of State's death. At the same time, there was no evidence of linear increases in the incidence of charisma-references over time (indicated by the non-significant time main effect) or of linear changes from predeath to post-death (indicated by the non-significant interaction).

\section{Discussion}

Study 2 provided further evidence of the impact of death on charisma from a largescale archival analysis of news reports about Heads of State who died in office in the 21 st century. In line with $\mathrm{H} 1$, results demonstrated that the proportion of charisma-referencing news items increases substantially from ante-mortem to post-mortem. Additional sensitivity analyses indicated that these results were robust and observed not only for the entire antemortem and post-mortem periods but also for the period of one-year ante-mortem and postmortem (thereby ruling out the possibility that the effect is due to a general increase in charisma references over time).

\section{General Discussion}

Results from two studies — a controlled experiment and a large archival study — contribute to our understanding of the nature and origins of charisma by demonstrating that charisma increases post-mortem. Specifically, our experimental study provided causal evidence that a leader who is believed to be dead is regarded as more charismatic than that same leader believed to be alive (supporting H1). Moreover, compared to a leader who was believed to be alive, a dead leader was seen to be more strongly fused with the collective that 
they represented (America) — an effect that accounted for the impact of death on perceived charisma (supporting H2). Providing further evidence of the death-charisma link, results from a large archival study of Heads of State who died in office in the 21st century, demonstrated that the proportion of charisma-referencing news items about a given leader increase significantly following their death (supporting $\mathrm{H} 1$ ).

These results have at least three important implications for literatures on leadership, charisma, and identity. First, they contribute to the literature on the nature and origins of charisma. Previous work suggests that charisma is a personal attribute, a reflection of individuals' skills, character, and personality (Bass \& Riggio, 2006; House \& Howell, 1992; Keller, 2006; Waldman et al., 2001). Along these lines, previous work has shown that charisma (and its extended sister construct transformational leadership) can be practiced and increased by participation in training and development (Antonakis et al., 2011; Frese, Beimel, \& Schoenborn, 2003; Towler, 2003). Our results extend these suggestions by indicating that charisma is, at least in part, a social inference that reflects, at least in part, one key factor that clearly lies beyond what a leader does and who they are — namely, death. Accordingly, charisma depends not only on what leaders $d o$ and are perceived to be doing, but also sometimes primarily — on the way in which perceivers make sense of and respond to them. Instantiating Shamir's (1995, p. 28) proposition that leaders' visions “are like pictures, better appreciated at a distance", the findings suggest that perceivers make sense of the irreversible physical distance that accompanies death through greater appreciation of a leader's visionary appeal.

Second, our findings extend previous work on the factors that structure inferences of charisma. In particular, previous research has shown that charisma is an inference that reflects either (a) observers' beliefs about the importance of leadership (Shamir, 1992), (b) perceptions that leaders are representative of shared identity (Platow et al., 2006; van 
Knippenberg \& van Knippenberg, 2005), or (c) perceptions of leaders' championing of interests associated with shared identity (Haslam et al., 2001; Steffens, Schuh, Haslam, Pérez, \& van Dick, 2015). Work by Meindl and colleagues (1985; Schyns et al., 2007) has shown that they reflect (d) group performance such that a leader is seen be more charismatic to the extent that the group (organization) that they have responsibility for is performing well (even though the effectiveness of charisma is more pronounced when the situation is ambiguous; Jacquart \& Antonakis, 2015). Counter to these various theses, the present findings indicate, rather more radically, that charisma need not be grounded in (perceptions of) any form of activity at all.

This is not to say that leaders' actions do not matter (because they do; Jones \& Olken, 2005). Nevertheless, our results show that a person is generally seen to be more charismatic and visionary once they personally are no longer able to do anything. Yet while at first glance, this pattern may appear paradoxical, our findings offer a parsimonious explanation of it. For they suggest that a person's capacity to be seen as charismatic is dependent on their being seen to be part of a valued social group (Ellemers, 2012). Leaders' charisma thus increases following their death partly because, once dead, they are seen to be connected more strongly with the collective that they represented in life. These findings also have methodological implications for the use and interpretation of biographical and historiometric approaches to the study of leadership in showing that death is an exogenous variable that is likely to affect the evaluation of the greatness and extraordinariness of leaders who are deceased.

Third, our work advances the literature on identity fusion and its implications for leadership and followership. In this regard, previous research has shown that identity fusion is important for our understanding of extreme forms of group behavior (Swann et al., 2012; Swann \& Buhrmester, 2015). For instance, Swann and colleagues have shown that people 
who feel strongly connected with a country are more likely to be willing to sacrifice themselves for that country (Swann, Gómez, Dovidio, Hart, \& Jetten, 2010). Turning this around, the present research demonstrates that death is also an antecedent of a person's perceived connectedness to a collective. Indeed, we show that increased connectedness with a social group following death explains why charismatic appeal increases post-mortem. This in turn suggests that a person's (perceived) oneness with a collective is also important for other less-extreme but equally important phenomena — notably, their inspirational appeal. In this way too, our findings accord with suggestions that a person's relationship with, and embodiment of, a valued identity is a basis for their capacity to influence others (Haslam et al., 2011; Steffens et al., 2014; van Knippenberg, 2011).

\section{Limitations and Future Research}

The present research is not without limitations. In particular, the CFA results from Study 1 indicated some degree of misspecification of the model including both charisma and fusion (as indicated by a significant chi-square), suggesting that estimators of the latent factors could be biased (Kline, 2005). We recognize that in previous research the definition and operationalization of charisma has been unclear and imprecise (see Antonakis et al., 2016 van Knippenberg \& Sitkin, 2013). In this regard, we aimed to help move the field forwards (a) by using experimental and archival designs to examine the effects of an exogenous variable (death) on perceived charisma, and (b) in Study 1 by using a refined charisma scale guided by the definition provided by Antonakis and colleagues (2016). Nevertheless, in future research it would be useful to develop and validate reliable extended measurements of charisma (given the paucity of useful measurements at present) and then examine the extent to which the death-charisma link applies to different aspects of this construct (e.g., emotion, values). 
There was also evidence that the fusion scale (Gómez et al., 2011) had some level of misfit. Indeed, a detailed review of the seven items in this scale indicates some misalignment between the concept and its operationalization. In particular, there are four items that do not appear to assess accurately fusion (or connectedness) with a collective. Two of these items are awkwardly worded, which may increase the likelihood of misunderstandings ("His country was [target person]"; "[Target person]" was strong because of his country"), and the remaining items assess (behavioral) outcomes of fusion (“[Target person] did for his country more than any other Americans would do"; "[Target person] made his country strong"). In light of these findings and observations it seems that there would be value in future research that reviews and clarifies this construct.

In addition to issues of operationalization, one additional limitation of our studies is that we did not consider the extent to which perceivers' inferences of leader charisma depend on characteristics of those perceivers. This is an important issue, and one worth exploring in future research, because it can help clarify exactly how charisma is co-constructed by leaders and perceivers (Gardner \& Avolio, 1998; Meindl, 1995; Pillai \& Meindl, 1998). Along these lines, it seems plausible that the processes explored in the present studies would be more marked to the extent that perceivers identify strongly with the collectives that a given leader is a member of (Platow \& van Knippenberg, 2001; van Dijke \& De Cremer, 2008). This hypothesis remains to be tested. Moreover, it would be interesting to examine the extent to which the present relationship is moderated by perceiver characteristics that may bear on the importance that people place on death (e.g., their religiosity). Similarly, there would be value in research that examines not only the ways in which perceptions of a leader change following death but also how perceptions of that leader's work or output may change.

Furthermore, it would be worthwhile for future work to investigate the extent to which the death-charisma link extends beyond the contexts investigated here (e.g., those of 
business and sport) and to explore potential boundary conditions. In particular, following on from the Discussion of Study 1, where we noted that the death of the leader could be seen as somewhat heroic, it would be interesting to investigate the impact of type of death on the death-charisma link. Here we might anticipate that the relationship would be stronger to the extent that the nature of a leader's death underlines their contribution to an important collective (i.e., laying down one's life for the group). Furthermore, there would be value in examining whether the death-charisma link is more pronounced for leaders who (a) are assassinated and (b) seen by perceivers as "social movement" leaders (see also Yammarino et al., 2013). Finally, it would be interesting to examine to what extent post-mortem increases in perceived charisma extend to other characteristics (e.g., moral character and warmth) and, if it does, to examine their unique and overlapping aspects.

\section{Conclusion}

I don't want to achieve immortality through my work, I want to achieve it through not dying.

\section{Woody Allen}

In the present research, we examined the impact of death on perceptions of leaders' charisma. An experimental study provided causal evidence that a leader who is believed to be dead is seen to be more charismatic and visionary than that same person believed to be alive. Furthermore, it demonstrated that post-mortem increases in charisma arise from perceptions that the dead leader is seen to be more fused with the collective that they were a member of. Providing much broader evidence for a death-charisma link, a large archival analysis of news reports about Heads of States who died in office in the 21st century then showed a substantial increase in references to charisma following leaders' deaths.

The findings of these studies thus suggest that charisma is conferred on outstanding individuals not merely as a reflection of their achievements but also as a consequence of their 
perceived connection to a collective. And because this connection is consolidated by a leader's death, so too is their charisma. The apparent paradox here, then, is that mortality is the basis for a particular form of immortality — one that arises from a social connection to the group. Mr Allen, we have some bad news... 


\section{Footnotes}

1. Participants also indicated the extent to which the target was seen to be fused with science on seven items that were adapted to the referent science from the same identity fusion scale (Gómez et al., 2011; $\alpha=.85$ ). This measure was positively correlated with fusion with America $(r=.43, p<.001)$, and, as expected, also affected by the experimental manipulation, $F(1,390)=16.92, p<.001, M D=.40$, $95 \%$ CIs $[.21, .60], d=.41$. Because it is not possible to test simultaneously endogeneity of a potential second mediator given that we have only one exogenous variable (i.e., the experimental manipulation), we cannot resolve issues of endogeneity of this measure with certainty and thus refrain from discussing it further.

2. Analysis of the eight-item charisma scale $(\alpha=.88)$ yielded virtually identical results, with a significant effect of experimental condition on charisma, $F(1,390)=10.09, p=$ $.002, M D=.27,95 \%$ CIs $[.10, .43], d=.33$. Participants perceived the target person to be more charismatic when he was believed to be dead $(M=5.60,95 \%$ CIs [5.48, 5.71]) than when he was believed to be alive $(M=5.33$, 95\%CIs [5.22, 5.45]). We also assessed leader vision, which has been conceptualized as an integral part of charisma (Awamleh, \& Gardner, 1999; House \& Shamir, 1993), using the five-item vision-subscale ( $\alpha=.88$ ) from the Transformational Leadership Behavior Scale from Podsakoff, MacKenzie, and Bommer (1996). Vision was moderately-to-strongly positively correlated with charisma $(r=.59, p<.001)$ and results were largely identical to those for charisma (with an effect of experimental condition on vision: $F(1,390)=5.95, p=.015, M D=.26,95 \%$ CIs $[.05, .46], d=.24)$. To avoid redundancy, we refrain from discussing results for this measure in greater detail.

3. We also recorded the overall time between the start and end of the survey capturing the time that respondents took from studying informed consent and general 
instructions, studying experimental materials, responding to scales and providing demographic variables, to reading the debriefing. The median response time was 544 seconds (Inter-Quartile Range: 418 to 712). An additional analysis excluding responses of participants who took less than five minutes from start to finish of the experiment $(n=25)$ yielded virtually identical results — the experimental condition had a significant impact on fusion with America, $F(1,365)=14.73, p<.001$, and charisma, $F(1,365)=6.54, p=.011$.

4. We conducted exploratory analyses assessing whether the effect of death on charisma was moderated by respondents' age and gender. Analysis examining age as a moderator revealed a significant main effect of condition, $\beta=.14, t(388)=2.81, p=$ .005 , and a non-significant effect of age on charisma at Step $1, \beta=.06, t(388)=1.25$, $p=.213$. Adding the interaction term at Step 2 indicated a non-significant interaction term between condition and age, $\beta=.08, t(387)=.99, p=.321$. Additional analyses examining whether the effect of condition was moderated by gender (female $=0$; male $=1)$ revealed a significant effect of condition, $\beta=.12, t(389)=2.32, p=.021$, and a significant effect of gender, $\beta=-.19, t(389)=3.75, p<.001$, indicating that female respondents regarded the target leader as more charismatic. However, the interaction term was non-significant, $\beta=.02, t(388)=.20, p=.840$, providing no evidence that the effect was moderated by respondents' age or gender (degrees of freedom for moderation by age and gender vary due to one missing data point in age). 


\section{References}

Antonakis, J., Fenley, M., \& Liechti, S. (2011). Can charisma be taught? Tests of two interventions. Academy of Management Learning \& Education, 10, 374-396.

Antonakis, J., Bastardoz, N., Jacquart, P., \& Shamir, B. (2016). Charisma: An ill-defined and ill-measured gift. Annual Review of Organizational Psychology and Organizational Behavior, 3. Advance online publication. doi:10.1146/annurev-orgpsych-041015-062305. Antonakis, J., Bendahan, S., Jacquart, P., \& Lalive, R. (2010). On making causal claims: A review and recommendations. The Leadership Quarterly, 21, 1086-1120.

Antonakis, J., Bendahan, S., Jacquart, P., \& Lalive, R. (2014). Causality and endogeneity: Problems and solutions. In D. V. Day (Ed.), The Oxford Handbook of Leadership and Organizations (pp. 93-117). New York: Oxford University Press.

Aral, S., \& Walker, D. (2012). Identifying influential and susceptible members of social networks. Science, 337, 337-341.

Awamleh, R., \& Gardner, W. L. (1999). Perceptions of leader charisma and effectiveness: The effects of vision content, delivery, and organizational performance. The Leadership Quarterly, 10, 345-373.

Bass, B. M., \& Avolio, B. J. (2004). Multifactor leadership questionnaire: Manual leader form, rater, and scoring key for MLQ (Form 5x-Short). Redwood City, CA: Mind Garden.

Bass, B. M., \& Riggio, R. E. (2006). Transformational leadership. Mahwah: Lawrence Erlbaum Associates Publishers.

Berson, Y., Shamir, B., Avolio, B. J., \& Popper, M. (2001). The relationship between vision strength, leadership style, and context. The Leadership Quarterly, 12, 53-73.

Brandes, L., Nüesch, S., \& Franck, E. (2016). Death-related publicity as informational advertising: evidence from the music industry. Marketing Letters, 27, 143-157.

Bryman, A. (1992). Charisma and leadership in organizations. London: Sage Publications. 
Burke, B. L., Martens, A., \& Faucher, E. H. (2010). Two decades of terror management theory: A meta-analysis of mortality salience research. Personality and Social Psychology Review, 14, 155-195.

Burns, J. M. (1978). Leadership. New York: Harper \& Row.

Cohen, F., Solomon, S., Maxfield, M., Pyszczynski, T., \& Greenberg, J. (2004). Fatal attraction: The effects of mortality salience on evaluations of charismatic, task-oriented, and relationship-oriented leaders. Psychological Science, 15, 846-851.

Conger, J. A., \& Kanungo, R. N. (1987). Toward a behavioral theory of charismatic leadership in organizational settings. Academy of Management Review, 12, 637-647.

Conger, J. A., \& Kanungo, R. N. (1998). Charismatic leadership in organizations. Thousand Oaks: Sage Publications.

Conger, J. A., \& Kanungo, R. N. (1994). Charismatic leadership in organizations: Perceived behavioral attributes and their measurement. Journal of Organizational Behavior, 15, $439-452$.

Cook, T. D. (2008). "Waiting for life to arrive": A history of the regression-discontinuity design in psychology, statistics and economics. Journal of Econometrics, 142, 636-654.

Den Hartog, D. N., \& Verburg, R. M. (1997). Charisma and rhetoric: Communicative techniques of international business leaders. The Leadership Quarterly, 8, 355-391.

DeSimone, J. A., Harms, P. D., \& DeSimone, A. J. (2015). Best practice recommendations for data screening. Journal of Organizational Behavior, 36, 171-181.

Dow Jones \& Company (2015). Factiva Database. Retrieved 03 March 2015 from https://global-factiva-com.

Emrich, C. G., Brower, H. H., Feldman, J. M., \& Garland, H. (2001). Images in words: Presidential rhetoric, charisma, and greatness. Administrative Science Quarterly, 46, 527557. 
Ellemers, N. (2012). The group self. Science, 336, 848-852.

Frese, M., Beimel, S., \& Schoenborn, S. (2003). Action training for charismatic leadership: Two evaluations of studies of a commercial training module on inspirational communication of a vision. Personnel Psychology, 56, 671-697.

Gardner, W. L., \& Avolio, B. J. (1998). The charismatic relationship: A dramaturgical perspective. Academy of Management Review, 23, 32-58.

Goemans, H. E., Gleditsch, K. S., \& Chiozza, G. (2009). Introducing Archigos: A dataset of political leaders. Journal of Peace Research, 46, 269-283.

Gómez, A., Brooks, M. L., Buhrmester, M. D., Vázquez, A., Jetten, J., \& Swann Jr, W. B. (2011). On the nature of identity fusion: Insights into the construct and a new measure. Journal of Personality and Social Psychology, 100, 918-933.

Harms, P. D., \& DeSimone, J. A. (2015). Caution! MTurk Workers Ahead-Fines Doubled. Industrial and Organizational Psychology, 8, 183-190.

Haslam, S. A. (2001). Psychology in organizations: The social identity approach. London: Sage.

Haslam, S. A., Platow, M. J., Turner, J. C., Reynolds, K. J., McGarty, C., Oakes, P. J., ... \& Veenstra, K. (2001). Social identity and the romance of leadership: The importance of being seen to be 'doing it for us'. Group Processes \& Intergroup Relations, 4, 191-205. Haslam, S. A., Reicher, S. D., \& Platow, M. J. (2011). The new psychology of leadership: Identity, influence and power. New York: Psychology Press.

Hayes, A. F. (2013) Introduction to mediation, moderation, and conditional process analysis: A regression-based approach. New York: Guilford Press.

Heracleous, L. \& Klaering, L. A. (2014). Charismatic leadership and rhetorical competence: An analysis of Steve Job's rhetoric. Group and Organization Management, 39, 131-161. 
House, R. J. (1977). A 1976 Theory of Charismatic Leadership. In J. G. Hunt, \& L. L. Larson (Eds.), The Cutting Edge (pp. 189-207). Carbondale, Southern Illinois: University Press.

House, R. J., \& Howell, J. M. (1992). Personality and charismatic leadership. The Leadership Quarterly, 3, 81-108.

House, R. J., \& Shamir, B. (1993). Toward the integration of transformational, charismatic, and visionary theories. In M. M. Chemers, \& R. Ayman (Eds.), Leadership theory and research: Perspectives and directions (pp. 167-188). San Diego: Academic Press.

House, R. J., Spangler, W. D., \& Woycke, J. (1991). Personality and charisma in the US presidency: A psychological theory of leader effectiveness. Administrative Science Quarterly, 36, 364-396.

Howell, J. M., \& Shamir, B. (2005). The role of followers in the charismatic leadership process: Relationships and their consequences. Academy of Management Review, 30, 96112.

Jacquart, P., \& Antonakis, J. (2015). When does charisma matter for top-level leaders? Effect of attributional ambiguity. Academy of Management Journal, 58, 1051-1074.

Jones, B. F., \& Olken, B. A. (2004). Do leaders matter? National leadership and growth since World War II. Quarterly Journal of Economics, 120, 835-864.

Judge, T. A., \& Piccolo, R. F. (2004). Transformational and transactional leadership: A metaanalytic test of their relative validity. Journal of Applied Psychology, 89, 755-768.

Keller, R. T. (2006). Transformational leadership, initiating structure, and substitutes for leadership: A longitudinal study of research and development project team performance. Journal of Applied Psychology, 91, 202-210.

Kline, R. B. (2015). Principles and practice of structural equation modeling (4th ed.). New York: Guilford Press. 
Kosloff, S., Greenberg, J., \& Solomon, S. (2010). The effects of mortality salience on political preferences: The roles of charisma and political orientation. Journal of Experimental Social Psychology, 46, 139-145.

Landers, R. N., \& Behrend, T. S. (2015). An inconvenient truth: Arbitrary distinctions between organizational, Mechanical Turk, and other convenience samples. Industrial and Organizational Psychology, 8, 142-164.

Ligon, G. S., Hunter, S. T., \& Mumford, M. D. (2008). Development of outstanding leadership: A life narrative approach. The Leadership Quarterly, 19, 312-334.

Lowe, K. B., Kroeck, K. G., \& Sivasubramaniam, N. (1996). Effectiveness correlates of transformational and transactional leadership: A review of the mlq literature. The Leadership Quarterly, 7, 385-425.

Meindl, J. R. (1995). The romance of leadership as a follower-centric theory: A social constructionist approach. The Leadership Quarterly, 6, 329-341.

Meindl, J. R., Ehrlich, S. B., \& Dukerich, J. M. (1985). The romance of leadership. Administrative Science Quarterly, 30, 78-102.

Mio, J. S., Riggio, R. E., Levin, S., \& Reese, R. (2005). Presidential leadership and charisma: The effects of metaphor. The Leadership Quarterly, 16, 287-294.

Mumford, M. D. (Ed.). (2006). Pathways to outstanding leadership: A comparative analysis of charismatic, ideological, and pragmatic leadership. Mahwah, NJ: Erlbaum Press.

Mumford, M. D., Hunter, S. T., Friedrich, T. L., \& Caughron, J. J. (2009). Charismatic, ideological, and pragmatic leadership: An examination of multi-level influences on emergence and performance. Research in Multi-Level Issues, 8, 79-116.

O'Connor, J. A., Mumford, M. D., Clifton, T. C., Gessner, T. E., \& Connelly, M. S. (1995). Charismatic leaders and destructiveness: An historiometric study. The Leadership Quarterly, 6, 529-555. 
Paterson, T. A., Harms, P. D., Steel, P., \& Credé, M. (2016). An assessment of the magnitude of effect sizes evidence from 30 years of meta-analysis in management. Journal of Leadership \& Organizational Studies, 23, 66-81.

Pillai, R., \& Meindl, J. R. (1998). Context and charisma: A" meso" level examination of the relationship of organic structure, collectivism, and crisis to charismatic leadership. Journal of Management, 24, 643-671.

Platow, M. J., Haslam, S. A., Reicher, S. D., \& Steffens, N. K. (2015). There is no leadership if no-one follows: Why leadership is necessarily a group process. International Coaching Psychology Review, 10, 20-37.

Platow, M. J., \& van Knippenberg, D. (2001). A social identity analysis of leadership endorsement: The effects of leader ingroup prototypicality and distributive intergroup fairness. Personality and Social Psychology Bulletin, 27, 1508-1519.

Platow, M. J., van Knippenberg, D., Haslam, S. A., Knippenberg, B., \& Spears, R. (2006). A special gift we bestow on you for being representative of us: Considering leader charisma from a self $\square$ categorization perspective. British Journal of Social Psychology, 45, 303320.

Podsakoff, P. M., MacKenzie, S. B., \& Bommer, W. H. (1996). Transformational leader behaviors and substitutes for leadership as determinants of employee satisfaction, commitment, trust, and organizational citizenship behaviors. Journal of Management, 22, 259-298.

Radford, S. K., \& Bloch, P. H. (2013). Consumers' online responses to the death of a celebrity. Marketing Letters, 24, 43-55.

Rees, L. (2012). The dark charisma of Adolf Hitler. London: Ebury Press.

Schyns, B., Felfe, J., \& Blank, H. (2007). Is charisma hyper-romanticism? Empirical evidence from new data and a meta-analysis. Applied Psychology, 56, 505-527. 
Seyranian, V., \& Bligh, M. C. (2008). Presidential charismatic leadership: Exploring the rhetoric of social change. The Leadership Quarterly, 19, 54-76.

Shamir, B. (1992). Attribution of influence and charisma to the leader: The romance of leadership revisited. Journal of Applied Social Psychology, 22, 386-407.

Shamir, B. (1995). Social distance and charisma: Theoretical notes and an exploratory study. The Leadership Quarterly, 6, 19-47.

Shamir, B., Arthur, M. B., \& House, R. J. (1994). The rhetoric of charismatic leadership: A theoretical extension, a case study, and implications for research. The Leadership Quarterly, 5, 25-42.

Simonton, D. K. (1991). Predicting presidential greatness: An alternative to the Kenney and Rice Contextual Index. Presidential Studies Quarterly, 21, 301-305.

Simonton, D. K. (2009). Presidential leadership styles: How do they map onto charismatic, ideological, and pragmatic leadership? Research in Multi-Level Issues, 8, 123-133.

Steffens, N. K., Haslam, S. A., \& Reicher, S. D. (2014). Up close and personal: Evidence that shared social identity is a basis for the 'special' relationship that binds followers to leaders. The Leadership Quarterly, 25, 296-313.

Steffens, N. K., Haslam, S. A., Reicher, S. D., Platow, M. J., Fransen, K., Yang, J., Jetten, J., Ryan, M. K., Peters, K. O. and Boen, F. (2014). Leadership as social identity management: Introducing the Identity Leadership Inventory (ILI) to assess and validate a four-dimensional model. The Leadership Quarterly, 25, 1004-1025.

Steffens, N. K., Schuh, S. C., Haslam, S. A., Pérez, A., \& van Dick, R. (2015). 'Of the group' and 'for the group': How followership is shaped by leaders' prototypicality and group identification. European Journal of Social Psychology, 45, 180-190.

Swann, W. B., \& Buhrmester, M. D. (2015). Identity fusion. Current Directions in Psychological Science, 24, 52-57. 
Swann, W. B., Gómez, Á., Dovidio, J. F., Hart, S., \& Jetten, J. (2010). Dying and killing for one's group: Identity fusion moderates responses to intergroup versions of the trolley problem. Psychological Science, 21, 1176-1183.

Swann, W. B., Jetten, J., Gómez, A., Whitehouse, H., \& Bastian, B. (2012). When group membership gets personal: a theory of identity fusion. Psychological Review, 119, 441456.

Thistlethwaite, D. L., \& Campbell, D. T. (1960). Regression-discontinuity analysis: An alternative to the ex post facto experiment. Journal of Educational Psychology, 51, 309317.

Thomas, G., Martin, R., \& Riggio, R. E. (2013). Leading groups: Leadership as a group process. Group Processes \& Intergroup Relations, 16, 3-16.

Towler, A. J. (2003). Effects of charismatic influence training on attitudes, behavior, and performance. Personnel Psychology, 56, 363-381.

Ursprung, H. W., \& Wiermann, C. (2011). Reputation, price, and death: An empirical analysis of art price formation. Economic Inquiry, 49, 697-715.

van Dijke, M., \& De Cremer, D. (2008). How leader prototypicality affects followers' status: The role of procedural fairness. European Journal of Work and Organizational Psychology, 17, 226-250.

van Knippenberg, B., \& van Knippenberg, D. (2005). Leader self-sacrifice and leadership effectiveness: The moderating role of leader prototypicality. Journal of Applied Psychology, 90, 25-37.

van Knippenberg, D. (2011). Embodying who we are: Leader group prototypicality and leadership effectiveness. The Leadership Quarterly, 22, 1078-1091. 
van Knippenberg, D., \& Sitkin, S. B. (2013). A critical assessment of charismaticTransformational leadership research: Back to the drawing board? The Academy of Management Annals, 7, 1-60.

Waldman, D. A., Ramirez, G. G., House, R. J., \& Puranam, P. (2001). Does leadership matter? CEO leadership attributes and profitability under conditions of perceived environmental uncertainty. Academy of Management Journal, 44, 134-143.

Wang, G., Oh, I. S., Courtright, S. H., \& Colbert, A. E. (2011). Transformational leadership and performance across criteria and levels: A meta-analytic review of 25 years of research. Group \& Organization Management, 36, 223-270.

Weber, M. (1992/1980). Wirtschaft und Gesellschaft [Economy and society]. Mohr: Siebeck. Wikipedia (2015). Retrieved 03 March 2015 from: http://en.wikipedia.org/wiki/List_of_heads_of_state_and_government_who_died_in_offi ce.

Yammarino, F. J., Mumford, M. D., Serban, A., \& Shirreffs, K. (2013). Assassination and leadership: Traditional approaches and historiometric methods. The Leadership Quarterly, 24, 822-841. 


\section{Tables and Figures}

Table 1. Means, standard deviations, and bivariate correlations between variables.

\begin{tabular}{lccccc}
\hline \multicolumn{1}{c}{ Variable } & Mean & $S D$ & 1. & 2. & 3. \\
\hline 1. Experimental Condition & 0.50 & 0.50 & - & & \\
2. Fusion with America & 4.44 & 1.21 & $.16^{* *}$ & - & \\
3. Charisma & 6.04 & 0.82 & $.14^{* *}$ & $.36^{* *}$ & - \\
\hline
\end{tabular}

Note. ${ }^{*} p<.05,{ }^{* *} p<.01$. Experimental Condition: alive and dead leader conditions coded as 0 and 1 , respectively. 
Table 2. Means (standard deviations in parenthesis), inferential statistics, and effect sizes as a function of experimental condition (alive versus alive person)

\begin{tabular}{lcccc}
\hline & \multicolumn{2}{c}{ Experimental Condition } & \multicolumn{2}{c}{ Statistics and Effect Size } \\
Derson believed to & $\begin{array}{c}\text { Person believed to } \\
\text { be dead }(n=195)\end{array}$ & $F(1,390)$ & Cohen's $d$ \\
\hline Fusion with America & $4.25(1.18)$ & $4.63(1.20)$ & $9.81^{* *}$ & .32 \\
Charisma & $5.93(.79)$ & $6.15(.84)$ & $7.58^{* *}$ & .28 \\
\hline
\end{tabular}

Note. ${ }^{*} p<.05 .{ }^{* *} p<.01$. 
Biography of a Person who is Alive

\section{Life of a Scientific Crusader}

Richard Din (1987) is an American scientist who lives on San Francisco's Treasure Island and works at the Northern California Institute for Research and Education (NCIRE).

His research is directed towards developing a vaccine that would protect people against the dangerous bacterium known as Neisseria

Biography of a Person who is Dead

\section{Death of a Scientific Crusader}

Richard Din (1987 to 2012) was an American scientist who lived on San Francisco's Treasure Island and worked at the Northern California Institute for Research and Education (NCIRE).

His research was directed towards developing a vaccine that would protect people against the dangerous bacterium known as Neisseria

Figure 1. Experimental design: Excerpts from the biography of the alive and dead scientist, Richard Din. 


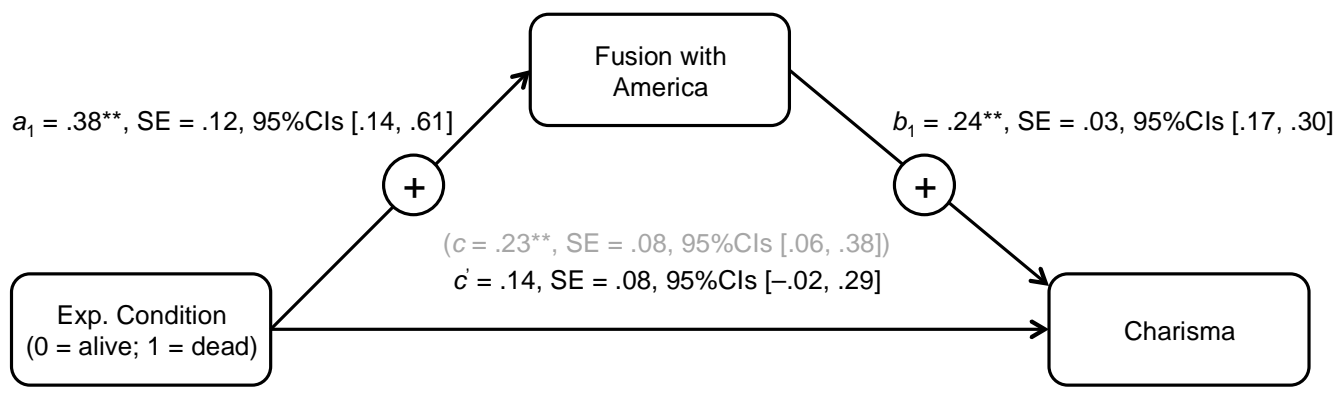

Figure 2. The direct and indirect effects of experimental condition through connectedness (identity fusion) with America on charisma. Asterisks indicate significant coefficients $\left({ }^{* *} p<\right.$ $.01)$.

Note. Mediation results from the 2SLS model yielded consistent results: the experimental condition was significantly associated with fusion with America, $a=.38, S E=.12,95 \% \mathrm{CIs}$ $[.14, .62]$, and fusion with America, in turn, was significantly associated with charisma, $a=$ $.70, S E=.21,95 \%$ CIs $[.28,1.13]$ (bootstrapped). Finally, 2SLS results for the reduced model that omitted the mediator indicated a significant effect of the experimental condition on charisma, $c=.26, S E=.09,95 \%$ CIs $[.10, .43]$ (bootstrapped). 


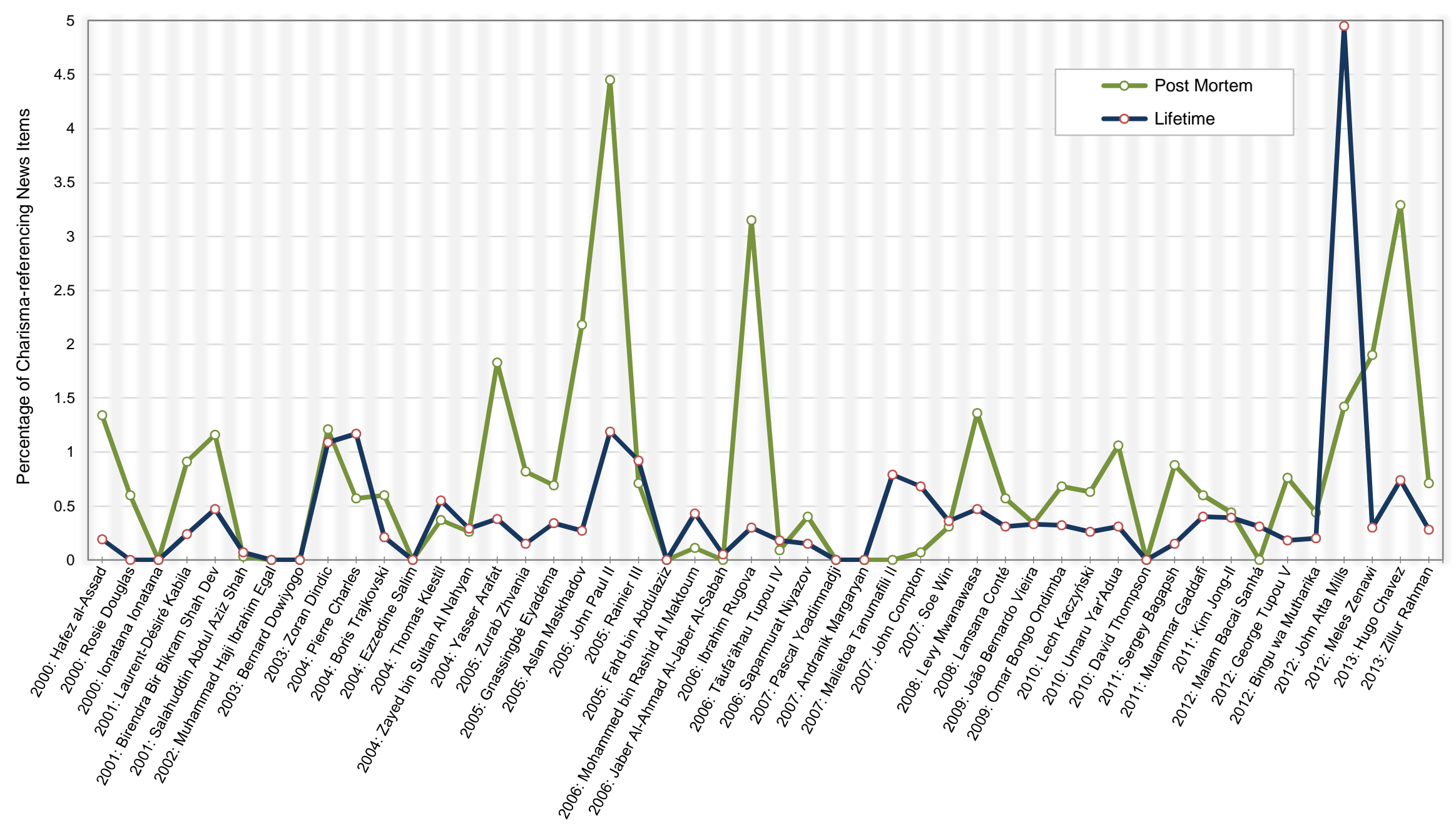

Figure 3. The effect of death on percentage of charisma-referencing news items $(N=2,402,171)$. The graph displays the percentage of charismareferencing news reports for Heads of State who died in office in $21^{\text {st }}$ century during their lifetime and post-mortem. 